Vol. 11, n² | 2007

Varia

\title{
Barry Godfrey, Graeme Dunstall, Crime and Empire 1840-1940; Criminal justice in local and global context
} Cullompton, Willan Publishing, 2005, 253 pp., ISBN 843921073

\section{Georgina Sinclair}

\section{(2) OpenEdition}

\section{Journals}

Electronic version

URL: https://journals.openedition.org/chs/131

DOI: $10.4000 /$ chs. 131

ISSN: 1663-4837

Publisher

Librairie Droz

Printed version

Date of publication: 1 December 2007

Number of pages: 155-157

ISBN: 978-2-600-01224-9

ISSN: 1422-0857

Electronic reference

Georgina Sinclair, "Barry Godfrey, Graeme Dunstall, Crime and Empire 1840-1940; Criminal justice in local and global context", Crime, Histoire \& Sociétés / Crime, History \& Societies [Online], Vol. 11, n² | 2007, Online since 15 January 2009, connection on 23 March 2022. URL: http://journals.openedition.org/ chs/131; DOl: https://doi.org/10.4000/chs. 131

This text was automatically generated on 23 March 2022.

(C) Droz 


\title{
Barry Godfrey, Graeme Dunstall, Crime and Empire 1840-1940; Criminal justice in local and global context
}

\author{
Cullompton, Willan Publishing, 2005, 253 pp., ISBN 843921073
}

\author{
Georgina Sinclair
}

\section{REFERENCES}

Barry Godfrey, Graeme Dunstall, Crime and Empire 1840-1940; Criminal justice in local and global context, Cullompton, Willan Publishing, 2005, 253 pp., ISBN 843921073

1 With a growing interest today in the fields of criminal justice history and the history of the British empire and commonwealth, Crime and Empire - an edited essay collection provides a welcome contribution. More importantly it taps into an under-researched area; that is the day-to-day management of crime and justice within a British imperial context. For that the editors should be congratulated in having gathered a broad selection of essays spanning both the 'old' (Australia and New Zealand) and the 'new' (India and South Africa) empire as well as Britain and Europe.

2 Barry Godfrey and Graeme Dunstall's introductory essay rightly points out that scholars and the general public alike have a growing awareness, and indeed interest, in the history of criminal justice, particularly where the legacy of colonisation (and no doubt decolonisation) has been felt. The editors have clearly been keen to demonstrate a multi-disciplinary approach with their eclectic selection of essays for Crime and Empire. Essentially each piece touches upon aspects of the history of crime and criminal justice within the 'legal regimes' of the British empire during the nineteenth and early part of the twentieth century. Crime and Empire offers essays that consider the transformation of legal codes; policing procedures and practice; punishment and criminal justice systems, many of which remain in situ today within former empire and commonwealth countries. The approach used here is both chronological (principally 
the nineteenth century) and thematic in scope. Crime and Empire also delivers in terms of the research methodologies used which spans the traditional 'empirical' through to the 'post-colonial' approach. In terms of the actual presentation, a somewhat more uniform approach would have benefited the ensemble; photographs only appear in two of the sixteen chapters.

Clive Emsley's essay spearheads the collection with an excellent survey of the changes that took place in terms of personnel and practices within the European criminal justice systems of the long nineteenth century. He discusses how this occurred across 'the European world' - countries with a dominant European culture that include Australia and New Zealand, which feature heavily within the collection. Importantly we have in Emsley's essay is a truly comparative piece that explains the progress of and changes to the legal codes and practices that impacted upon the emergence and perceptions of 'the criminal'. By extension this would have implications for the criminal justice systems of the other European empires of the nineteenth century. As Emsley intimates, the use of inter-disciplinarity can help us reach a clearer understanding of the changes to policing and justice systems per se. Certainly the historical backdrop of empire has a contemporary resonance. Indeed as Catharine Coleborne notes in a later essay on 'Crime, the legal archive and postcolonial histories', historians can usefully 'reinterpret' legal and colonial history through the prism of post-colonial theory. As she later argues, 'it means that we ought to try to reconceive of the past in the present, especially thinking about what drives us to understand the past'. This is also true of Mark Finnane's exploration of revisionism and counterrevisionism in the histories of colonial violence in nineteenth century 'frontier' Australia, which have become a popular field of enquiry. One only has to consider, for example Caroline Elkins's Britain's Gulag; The Brutal End of Empire in Kenya (London, 2005) and David Anderson's Histories of the Hanged; Britain's dirty war in Kenya and the end of the Empire (London, 2005). This has added to Crime and Empire's contemporary feel.

Whilst Crime and Empire strikes the right note in terms of the general issues raised, it would have benefited from a wider geographical sweep of essays (only one on India and one on South Africa) and the comparative element which lends itself so well to the study of empire and decolonisation. Julie Evan's case study on how authorities sought to regulate frontier violence in their quest for the development of 'normal order' in nineteenth century South Australia has arresting parallels with the developing European settler colonies of Kenya, Northern and Southern Rhodesia during the same era. Likewise Stefan Petrow's case study of whether a decentralised 'English' or a centralised 'Irish' policing model existed in Tasmania could be compared with the emergence of modern policing in nineteenth century India and the attempts to reconcile the policing models on offer. Dean Wilson's fascinating insight too into the 'symbolic dimension' of policing and how it shaped historical change through an examination of the Melbourne police and how beat policing was surpassed in its importance by new techno-scientific symbols (fingerprinting and radio communications) could have been linked to many of the same developments taking place within the police forces of both the metropole and empire. Again Richard Hill's valuable discussion of how policing in New Zealand could be linked to the Maori quest for autonomy - the so-called 'rangatiratanga'- discourse could have drawn from a wider comparative framework, given that all colonial police forces balanced the possibility of demands for independence from the police rank and file with overriding concerns for the need of a strong esprit de corps. Surprisingly perhaps, when it came to 
decolonisation, the majority of colonial police forces remained loyal to the British Crown.

5 That said Crime and Empire provides a springboard for further comparative studies of crime and criminal justice within an imperial context. Of particular value would be a collection of essays centred upon the long era of decolonisation, where the problems of reconciling native law and custom to the challenges faced by the colonial authorities when administering British criminal law became particularly virulent. It would certainly be useful to have several further edited volumes with greater geographical scope that addressed the core themes found within Crime and Empire.

\section{AUTHORS}

\section{GEORGINA SINCLAIR}

The University of Leeds, g.s.sinclair@leeds.ac.uk 